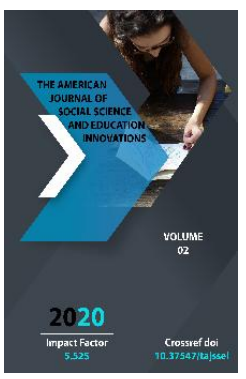

\title{
The Image Of Amir Temur In Figure Literature
}

\author{
Gavhar Ramazonovna Khodjieva \\ Teacher Of The Department Of Uzbek Literature Of Bukhara State University, Uzbekistan
}

Journal Website:

http://usajournalshub.c

om/index,php/tajssei

Copyright: Original

content from this work

may be used under the

terms of the creative

commons attributes

4.0 licence.

\section{ABSTRACT}

The article reveals the role of the genius savior of our people, historical hero Amir Temur in the history of the homeland, the destiny of the nation, the desire to understand national identity, the call to draw conclusions from historical memory on the example of Abdulla Aripov's poetic drama "Sahibkiron". The play creates a realistic image of Amir Temur. The article discusses the peculiarities of the historical dramas of the new period, the important aspects of the poetic drama, the structure of the work, the theme and content.

\section{KEYWORDS}

Drama, poetic drama, fiction, dialogue, monologue, philosophical depth, idea, historical drama, historical hero, historical reality, image, realistic image, episode.

\section{INTRODUCTION}

After the independence of our country, the self-awareness, self-esteem of our people, the feelings of national pride have been strengthened. It has become an important principle to reflect the glorious history of our people, the life and destiny of our great ancestors in the works and artistic researches of well-known representatives of Uzbek literature. Our artists began to express their views on the future of the nation, the 
development of the Motherland through their works, sometimes referring to history, sometimes to religious and moral ideas, and sometimes to current events. Consequently, a work of art conveys history, historical events, to a better public than historians. Because literature describes life figuratively and has the ability to have a wide aesthetic and moral impact on the reader. That is why our creators have created dozens of dramas related to the realities of each period and the names of historical figures. For example, novels, short stories, epics, a number of plays about Amir Temur and Temurids, Imam Bukhari, Ahmad Fergani, Alisher Navoi, Zahiriddin Babur, as well as other scholars and writers, kings and poets have been written and are still on the stage.

\section{MATERIALS AND METHODS}

Historical dramas created in the Uzbek drama of the new period require a special responsibility. Such works should help to change the spiritual and aesthetic world, the worldview of modern people. The uniqueness of the historical dramas of the new period is determined by the characteristics of historical heroes in the history of the Motherland, the fate of the nation, the desire to understand the national identity, the call to draw conclusions from historical memory. These historical works were written by our literary critics H.Abdusamatov[1], I.Yakubov [2], Sh.Hasanov, G.Murodov [3], G.Yusupova [4], N.Hasan [5], M.Umarova [6], R.Soibjonova, I.Jabborov [7] researched and published several articles in periodicals.

\section{RESULT AND DISCUSSION}

The first changes in this field of creativity began with the creation of the image of our great ancestor Amir Temur. Amir Temur is a "famous hero" who shook the world, an incomparable ruler. Thanks to independence, the main goal of the writers has been to glorify national values and national devotion by creating works about Sahibkiran, the genius savior of our people. The first example of a poetic drama in Uzbek literature was created by Fitrat, and the first drama about Amir Temur also belonged to Fitrat. The author's trade of "Temur sag'anasi" has not reached us. With this work, Fitrat was one of the first to bring the image of Amir Temur to our dramaturgy.

There are more than twenty poems about Amir Temur and Temurid princes, including Abdulla Aripov's "Sahibkiron", Odil Yakubov's "Testament to Generations", Khurshid Davron's "Boburshah" ("Missing"), Maruf Jalil's ("Amir Temur's Story"), "Amir Temur and Yildirim Boyazid" by Kilich Abdunabiev, "Amir Temur" by Tora Mirzo, "Humoyun qabul" by Urfon Otajon, "Jahongir" by Shavkat Pardaev, "Son of Time" by Turob Akbarkhodjaev, "Sahibkiron Temur" by Salohiddin Sirojiddinov, Asror Samad "Sahibkiron Temur" and Nasrullo Kasimov's "Tragedy of Amir Muzaffar" are historical works of different genres and levels.

It should be noted that in several works created during the former regime, the personality of Amir Temur was sharply condemned, the historical truth was distorted. The reason for the creation of many works dedicated to the personality of Amir Temur during the independence period is the objective assessment of his historical services. The poetic drama "Sahibkiron" written in 1995 by the People's Poet, Hero of Uzbekistan Abdulla Aripov is a big step in this direction. Abdulla Aripov's works are exemplary with their deep vitality, philosophical depth and richness of poetic ideas and observations. 
Unlike other dramas, the drama "Sahibkiron" created a realistic image of Timur and vividly reflected his role in the history of the country and the people.

The main focus of the drama is not on battles, but on the peculiarities of poetic drama: through dialogues and monologues, Timur's profound observations, thoughts, government, humanity and love for man are reflected. He valued people. His kindness and anger were immense. Timur was able to appreciate good, hardworking, honest people in any situation.

In the battle with Boyazid, the faithful Yasavi, who brought the good news of the capture of the sultan, rewarded Qasim by saying that he would marry his grandson. Qasim's father also served Amir Temur and was a soldier. He was martyred in the battle of Delhi. We try to justify our feedback through the episodes in the play.

Temur:

Bizning uchun g'oyat qutlug' mujda keltirding, (You have brought us good news)

O'g'lim, seni siylagayman bu mujda uchun,

(My son, I respect you for this good news)

Inshoolloh, Samarqandga qaytib borar chog'

(Inshallah, when I return to Samarkand)

Nigohingga berajakman bir nabiramni[8,428].

(I will give you a grandchild for your marriage $[8,428]$.)

Sahibkiron sold the land and severely punished the traitors. Although his life was spent in the throes of war, he sometimes had to shed the blood of unwilling people. As a result of the struggles of Amir Temur, thousands of innocent people were killed. It is true that the historical conditions of Sahibkiran's time demanded it. Amir Temur was one of the rulers of that time. Minister Muhammad Qovchin:

Balki Boyazid

(Maybe Boyazid)

Tavba qilib o'tirgandir, jur'ati so'nib.

(He may have repented, but his courage was gone)

Ko'z oldiga kelar balki, minglab kalladan,

(It comes to mind, perhaps, from thousands of heads)

Yasalajak minoralar, seldek oqqan qonlar... [8, 406]

(The towers to be built, the blood flowing like a flood ... [8, 406].)

Amir Temur became angry and called him "a man without a will", "a camel lost in this caravan". He removes his minister from office and orders him to be a horseman, to pick up severed heads in battle. By providing these images, A. Aripov tried to reveal the identity of Amir Temur. Because in history, the great Timur was condemned, in the imagination of people like Muhammad Kovchin, our great ancestor was a conqueror, engaged only in the intensity of the battle. At this point, Amir Temur clarifies this situation in his own words.

Temur:

Men hazrat emas, (I'm not a gentleman)

Men ham Temur deb atalmish oddiy bir banda...

( I am also an ordinary slave named Temur ...)

Boz ustiga fotih deb nom olgan zotman

(Moreover, I am called the conqueror)

Odam qavmi o'z qismatin sahrolarida

(The human race is in the wilderness)

Tashnalikdan labi qaqrab tentiragan chog',

(When his lips quiver with thirst)

Qultum suvdek kerak bo'ldim shekilli unga.

(I think I needed a sip of water)

Cheksiz cho'lda Insoniyat karvoni tarqab 
(The caravan of Humanity is scattered in the endless desert)

Bir-birlarin tepib, (Kicking each other)

Surib g'ujg'on bo'lgan payt.

(It's time to dump her)

Men ularni ipga tizdim bir sarbon bo'lib.

(I lined them up as a sarbon.)

Ko'hna tarix oldidagi xizmatim shuldir[8,407].

(This is my service to ancient history $[8,407]$.)

\section{CONCLUSION}

The scenes depicting Sahibkiran's devotion to the development of the nation and the Motherland, his public service and a number of human qualities not only evoke the truth in the history of our people, but also evoke feelings of patriotism. The drama is characterized by the fact that it covers almost all aspects of the life and work of Amir Temur. Although the scale of the events and images depicted is extremely diverse, they are all aimed at revealing the qualities of Sahibkiran's character.

In particular, his conversation with the barber, his attitude to the ministers, his struggle against the Mongols on the Syrdarya, Bibihanim, Mir Sayyid Baraka, Kaykhusrav, Shaykhulislam, Amir Hussein, Boyazid captured in the battle of Ankara, Hafiz Shirazi, Russian, Spanish, Chinese ambassadors, the qualities of humanity and supremacy are vividly manifested.

\section{REFERENCES}

1. Murodov G'. Eternity of Amir Temur.-T., "Science", 1994. Murodov G. "Moziy va badiiy adabiyot"- Bukhara, 1994.

2. Yusupova G. Artistic interpretation of the image of Amir Temur and the Temurids in modern Uzbek novels. candidate of sciences ... author ... dis ... -T., 2005.

3. Nodirkhan Hasan. Ahmad Yassavi and Amir Temur. Uzbek language and literature. 2008, № 4. -P. 17.

4. UmarovaM. Artistic time in historical drama.// Uzbek language and literature 2004, issue 6 - Pp.56-59.

5. Jabborov I. Historical theme in the work of A. Aripov.// Uzbek language and literature 2013, issue 3 - Pp.66-69.

6. Abdulla Oripov. Selected works Volume IV. Volume II. Poems and epics. Tashkent: Publishing House of Literature and Art named after G.Gulam, 2001. -492 p.

7. Timur's rules. - Tashkent: Publishing and Printing Association named after G. Gulom, 1991. - 144 p.

8. Turaev D. New Uzbek literature. $-\mathrm{T}$.: Fan, 2008. - $192 \mathrm{p}$.

9. Abdusamatov H. History and artistic interpretation.// Uzbek literature and art 2005, May 13.

10. Yoqubov I. Historical truth and artistic interpretation.// Uzbek language and literature 2008, issue 4 - P.30-38. 